UDC: 668.681-021.4:005.936.41-035.2(083.1)

L. Telezhenko, Doctor of Sciences, Professor,E-mail:telegenko@ukr.net ORCID 0000-0001-6675-2625, ResearcherID: O-8034-2018

Scopus Author ID: 57194025461

M. Napadovska, post-graduate student, E-mail: marinapadovska@gmail.com

ORCID 0000-0003-2682-5003

T.Pasternak, Master, E-mail: tanusha.pasternak@ukr.net Department of Technology of Restaurant and Healthy Food Odessa National Academy of Food Technologies, 112, Kanatna Str., 65039, Odessa, Ukraine, +38487124113

\title{
DEVELOPMENT OF A RECIPE FOR CRUSTILIANS WITH HIGH NUTRITIONAL VALUE
}

\begin{abstract}
Abstrakt
One of the most important problems of the population's nutrition is the high caloric content of flour confectionery products, due to their oversaturation with carbohydrate and fat components. This trend leads to micronutrient deficiencies, and later to metabolic problems and deteriorating health. In recent years, there has been an expansion of the range of waffles, improving technology through the wider introduction of various ingredients of plant origin. Crustilian is a crunchy product or component of a dish that has a crispy texture (waffles, cereal breads) or a surface (a crust of bread or potato balls with a fried crust). Crustilian is also used as a layer for cakes or desserts, which usually consists of waffle crumbs, chopped nuts and melted dark chocolate. There are still many variations for making crustilians. The range of applications of crustilian in the manufacture of sweet dishes is extremely wide. The nutritional value of crustilians is determined by the composition of raw materials and can be significantly increased due to the rational selection of components, the introduction of enrichments in the recipe, as well as technological processing, which increases their digestibility. Improving the technology of crucifers waffles by increasing their nutrient density will expand the range of products with functional ingredients, and enrichment of the micronutrient composition due to valuable plant raw materials will improve the nutritional value and organoleptic characteristics of the finished product. A line of crustilians with a high content of biologically active compounds has been developed due to the introduction of superfoods such as flax seeds, sesame seeds, sunflower and walnuts and peanuts into the product formulation. It is established that the use of peanuts and walnuts, in the composition, makes the dough less crispy and more fatty. The presence of flax and sesame does not reduce the crunchiness of the finished product, which is characteristic of crustilians, but, on the contrary, slightly increases this figure. It is proved that the index of nutritional density of crustilian made according to the developed recipe in comparison with the prototype is characterized by an increase in the index of nutritional density in three times, while the mass fraction of the macronutrients increases from 1.26 to 2.5 times, depending on the micronutrient. increases only 1.1 times.
\end{abstract}

Key words: crustilian, waffle products, vegetable raw materials, biological value, nutritional value, food density.

\section{Introduction}

The range of flour confectionery products sold today is quite wide and diverse. Among them, a significant share is accounted by waffles, due to high demand among consumers. One of the key reasons for this demand is their organoleptic properties (taste, original texture and specific crunchiness for Crustilians). However, such products are usually high calories and have an unbalanced composition due to the high content of fats, carbohydrates low content of dietary fiber and biologically active compounds. The reason for this is the intensification of production processes and the use for their production of refined raw materials, low-quality vegetable and animal fats, stabilizers, etc. New trends declaring the consumption of healthy foods require innovative approaches, including to the technology of Crustilian. Creation of new crustilian recipes based on traditional waffles, is possible by enrichment of plant componentssuperfoods and improvement of technological processes. Expanding of the range of waffle products through the regulation and improvement of the component composition will allow you to get healthy food products without a significant restructuring of technological processes. The nutritional value of crustilian is determined by the composition of raw materials and can be significantly increased by partially replacing the flour with seeds with a high index of food density, as well as using of economical processes.

\section{Literature review}

Development of innovative technologies of new products with the use of physiological and functional ingredients of plant origin to increase the nutritional and biological value is one of the relevant scientific directions. The studies of the use of plant and non-traditional raw materials are devoted to the works of MI Peresichny and VI Drobot. A recipe for waffles has been developed with the replacement of wheat flour with a mixture of rice and buckwheat flour[1]. There are studies on the use of powders from non-traditional vegetable raw materials in the technology of flour confectionery products $[2,3]$. However, the problem of finding and using new sources of natural raw materials has not been resolved yet and it relevant and promising. Therefore, we investigated the possibility of using non-traditional plant materials in the prescription composition of crustilian, along with the traditional one, in order to enrich the product with biological substances.

\section{Materials and methods}

The aim of the work is to develop a recipe for crustilian with increased nutritional integrity and improved consumer properties through the introduction of functional plant ingredients. 
Object of work: raw materials for the production of crustilians and the finished product.

Tasks of work:

- Justify the choice of plant raw materials for the production of crustilians.

- Develop a new high nutrient density crustilian recipe.

- Investigate the quality of the wafer sheet.

- Conduct research on physicochemical, microbiological and organoleptic parameters in finished products;

During the experimental research, physicochemical and rheological methods were used, which make it possible to assess the compliance of products with regulatory requirements and obtain data on changes in the structural and mechanical parameters of the products under study.

When also conducted organoleptic evaluation and determined:

- mass fraction of dry matter according to DSTU ISO 751-2004;

- determination of titrated acidity DSTU 4957: 2008;

- determination of active acidity DSTU ISO 7238-2001.

\section{Results of the study and their discussion}

In order to improve the recipe of waffle products, namely crustilla, in order to increase its nutritional density, it included such superfoods as flax seeds, sesame seeds, sunflower as well as walnuts and peanuts, which contain physiologically functional ingredients. The initial task is to use a combination of traditional and functional ingredients, the composition and ratio of which are determined taking into account the established physiological norms of their consumption and the impact on the commodity and consumer properties of the finished product.

The main component of waffle dough is flour. To obtain sheets of proper quality, it is necessary to use wheat flour containing $25 \ldots 32 \%$ of low gluten. Flour usually has an average protein level $(9.5 \%)$. Flour with a very low protein content is used to make brittle and light crustilians, and from flour with a high protein content (for example, baking flour) -are used to make hard waffles. Both types of flour can damage the wafer sheet when it is removed. An important indicator is also the relationship between flour and dough consistency and dry matter content. The higher the dry matter content of the waffle dough, the heavier the wafer sheet becomes, and conversely, the less dry matter, the lighter the finished product.

The absorption of water by flour is also very important, because the deviation of this indicator affects the consistency of the dough at any dry matter content. If the content of $\alpha$-amylase in the flour is high, when aged over time, the consistency of the dough deteriorates, especially in the heat. As a result of information search, technological experiment and analysis of the properties of different types of plant raw materials, three main components of plant origin were selected as ingredients for the production of crosstans, which allow to enrich the product with vitamins and minerals. Foods such as sunflower seeds, sesame seeds and flax, in contrast to wheat flour, have a higher content of protein and other nutrients. The nutritional density index of these ingredients is 3 times higher than that of wheat flour. The use of vegetable raw materials that contain antioxidants can also extend the shelf life of waffle dough products, provided that its quality is maintained. Studies show that when fat is present in the recipe, the surface of the waffles is smoother and smoother. The use of vegetable oil, in contrast to butter, reduces the viscosity of the dough and improves the quality of the wafer sheet. At the same time, as the amount of oil increases, the baking time increases and the strength and crunchiness of the sheet decreases. Peanuts contain more than $50 \%$ fat. Therefore, the use of peanuts and walnuts, due to the large amount of fat in the composition, makes the dough less crispy and more fatty. The presence of flax and sesame in the recipe does not reduce the crunchiness of the finished product, but on the contrary increases it and has almost no effect on the rheological properties of the dough.

Egg products, in particular melange, have a significant effect on the quality of the dough due to the presence of surfactants in it. Eggs are a source of both fat and emulsifier (lecithin), but some researchers say they also provide better quality for waffles and increase shelf life. The presence of melange improves the viscosity of the waffle dough and the taste of the waffle sheet. There is also a pattern that with increasing amount of melange decreases the strength of the sheet.

Based on the classic recipe of crustilian, a line of samples of crustacean analogues was developed, to the

Table 1 - Composition and ratio of components in the prescription compositions of crustilians

\begin{tabular}{|c|c|c|c|c|c|c|}
\hline \multirow[t]{2}{*}{ Storage } & \multicolumn{5}{|c|}{ The ratio of components, $\%$} & \multirow[b]{2}{*}{$\begin{array}{l}\text { Traditional } \\
\text { recipe }\end{array}$} \\
\hline & Recipe № 1 & Recipe №2 & Recipe №3 & Recipe №4 & Recipe №5 & \\
\hline Chicken egg & 17,5 & 17,5 & 17,5 & 17,5 & 17,5 & 17,5 \\
\hline Sugar & 11,0 & 11,0 & 11,0 & 11,0 & 111,0 & 111,0 \\
\hline Butter & 17,0 & 17,0 & 17,0 & 17,0 & 17,0 & 21,5 \\
\hline Wheat flour & 40 & 40 & 40 & 40 & 40 & 50 \\
\hline The oil is refined & 4,5 & 4,5 & 4 & 4,5 & $4,4,5$ & 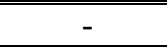 \\
\hline Sesame seeds & 10 & 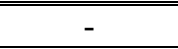 & 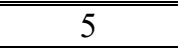 & 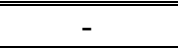 & 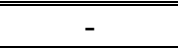 & 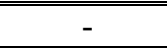 \\
\hline Flax seeds & - & 10 & 5 & - & - & - \\
\hline Walnuts & - & - & - & 10 & 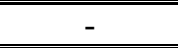 & 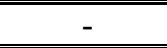 \\
\hline Peanut & 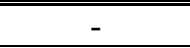 & 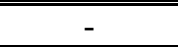 & 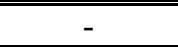 & 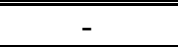 & 10 & - \\
\hline Total & 100 & 100 & 100 & 100 & 100 & 100 \\
\hline
\end{tabular}


recipe of which crushed sesame seeds, flax, walnut and peanut were introduced. Developed and processed 5 prescription compositions (Table 1) of crustilians and a classic prototype of the product.

According to the requirements for crustillan, namely brittle consistency and crunchiness, the assess-

Table 2 - Organoleptic characteristics of the compositions of the ingredients $f$ or the manufacture of crutches and the prototype

\begin{tabular}{|c|c|c|c|c|c|}
\hline $\begin{array}{l}\text { Recipe } \\
\text { number }\end{array}$ & Appearance & Consistency & Color & Taste & $\begin{array}{c}\text { Total number of } \\
\text { points (out of } 5 \\
\text { possible) } \\
\end{array}$ \\
\hline 1 & $\begin{array}{l}\text { The surface of the } \\
\text { crustilian with a } \\
\text { clear pattern with- } \\
\text { out swelling, dents } \\
\text { and cracks. }\end{array}$ & $\begin{array}{l}\text { Homogene- } \\
\text { ous, crunchy, } \\
\text { with sesame } \\
\text { seeds }\end{array}$ & $\begin{array}{l}\text { The color of the } \\
\text { waffles is from } \\
\text { light yellow to light } \\
\text { brown. The general } \\
\text { tone is typical of } \\
\text { waffles }\end{array}$ & $\begin{array}{l}\text { The taste is inherent in } \\
\text { this product, taking into } \\
\text { account the raw materi- } \\
\text { als used. Taste and } \\
\text { aroma of sesame }\end{array}$ & 4,6 \\
\hline 2 & $\begin{array}{l}\text { The surface of the } \\
\text { crustilian with a } \\
\text { clear pattern with- } \\
\text { out swelling, dents } \\
\text { and cracks. }\end{array}$ & $\begin{array}{l}\text { Homogeneous } \\
\text {, crispy, with } \\
\text { flakes }\end{array}$ & $\begin{array}{l}\text { The color of the } \\
\text { crustilian is from } \\
\text { light yellow to light } \\
\text { brown. The overall } \\
\text { color tone is the } \\
\text { same for all waffles }\end{array}$ & $\begin{array}{l}\text { The taste is inherent in } \\
\text { this product, taking into } \\
\text { account the raw materi- } \\
\text { als used. Taste and aro- } \\
\text { ma of sesame. No for- } \\
\text { eign tastes and odors }\end{array}$ & 4,6 \\
\hline 3 & $\begin{array}{l}\text { The surface of the } \\
\text { crustilian with a } \\
\text { clear pattern with- } \\
\text { out swelling, dents } \\
\text { and cracks. }\end{array}$ & $\begin{array}{l}\text { Homogene- } \\
\text { ous, crunchy, } \\
\text { with flakes } \\
\text { and sesame } \\
\text { seeds }\end{array}$ & $\begin{array}{l}\text { The color of the } \\
\text { crustilian is from } \\
\text { light yellow to light } \\
\text { brown. The overall } \\
\text { color tone is the } \\
\text { same for all waffles }\end{array}$ & $\begin{array}{l}\text { The taste is inherent in } \\
\text { this product, taking into } \\
\text { account the raw materi- } \\
\text { als used. Taste and aro- } \\
\text { ma of sesame and flax. } \\
\text { No foreign tastes and } \\
\text { odors }\end{array}$ & 4,8 \\
\hline 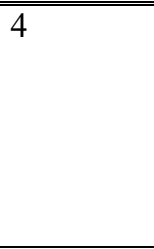 & $\begin{array}{l}\text { The surface of the } \\
\text { crustilian with a } \\
\text { clear pattern with- } \\
\text { out swelling, dents } \\
\text { and cracks. }\end{array}$ & $\begin{array}{l}\text { Homogene- } \\
\text { ous, soft, } \\
\text { greasy with } \\
\text { walnut patch- } \\
\text { es }\end{array}$ & $\begin{array}{l}\text { The color of the } \\
\text { crustilian is from } \\
\text { light yellow to light } \\
\text { brown. The overall } \\
\text { color tone is the } \\
\text { same for all waffles }\end{array}$ & $\begin{array}{l}\text { The taste is inherent in } \\
\text { this product, taking into } \\
\text { account the raw materi- } \\
\text { als used. Without } \\
\text { foreign tastes and odors }\end{array}$ & 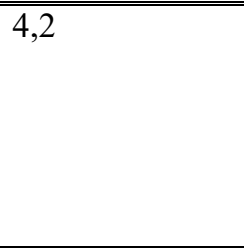 \\
\hline$\overline{25}$ & $\begin{array}{l}\text { The surface of the } \\
\text { crustilian with a } \\
\text { clear pattern with- } \\
\text { out swelling, dents } \\
\text { and cracks. }\end{array}$ & $\begin{array}{l}\text { Homogene- } \\
\text { ous, soft, } \\
\text { greasy with } \\
\text { peanuts }\end{array}$ & $\begin{array}{l}\text { The color of the } \\
\text { crustilian is from } \\
\text { light yellow to light } \\
\text { brown. The overall } \\
\text { color tone is the } \\
\text { same for all waffles }\end{array}$ & $\begin{array}{l}\text { The taste is inherent in } \\
\text { this product, taking into } \\
\text { account the raw materi- } \\
\text { als used.Without foreign } \\
\text { tastes and odors }\end{array}$ & 3,5 \\
\hline Prototype & $\begin{array}{l}\text { The surface of the } \\
\text { crustilian with a } \\
\text { clear pattern with- } \\
\text { out swelling, dents } \\
\text { and cracks. }\end{array}$ & $\begin{array}{l}\text { Homogeneous } \\
\text {, crunchy }\end{array}$ & $\begin{array}{l}\text { Color from light } \\
\text { yellow to light } \\
\text { brown. Color tone } \\
\text { for all waffles }\end{array}$ & $\begin{array}{l}\text { The taste is inherent in } \\
\text { this product, taking into } \\
\text { account the raw materi- } \\
\text { als used. Without } \\
\text { foreign tastes and odors }\end{array}$ & 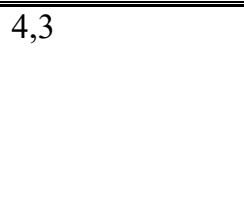 \\
\hline
\end{tabular}

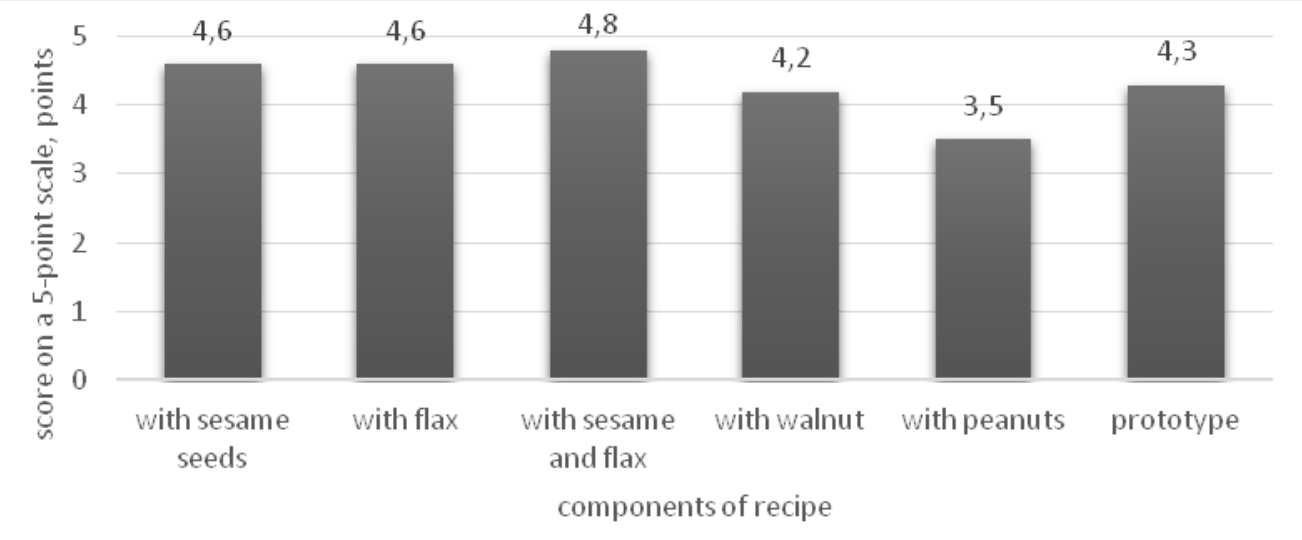

components of recipe ment of organoleptic characteristics and comparative characteristics of the crunchiness of the developed crustillan and the prototype (Table 2) (Figure 1).

During the organoleptic evaluation of 6 prescription compositions, it was determined that the pre-

Fig. 1 - Crunchiness of crustilians according to the maximum estimation 
Table 3 - The content of vitamins in the prototype and developed formulas of crustilian.

\begin{tabular}{|c|c|c|c|c|c|c|c|c|c|c|c|}
\hline $\begin{array}{l}\text { Raw materi- } \\
\text { als, } \% \text { in the } \\
\text { finished } \\
\text { product }\end{array}$ & $\begin{array}{l}\text { Vita- } \\
\text { min } \\
\text { A, } \\
\text { mcg }\end{array}$ & $\begin{array}{c}\text { Beta } \\
\text { Caroten } \\
\text { e, mcg }\end{array}$ & $\begin{array}{c}\text { Vita- } \\
\text { min } \\
\mathrm{B}_{1}, \\
\text { meg }\end{array}$ & $\begin{array}{l}\text { Vita- } \\
\text { min } \\
\mathrm{B}_{2}, \\
\mathrm{mcg}\end{array}$ & $\begin{array}{c}\text { Vita- } \\
\text { min } \\
\mathrm{B}_{5}, \mathrm{mg}\end{array}$ & $\begin{array}{c}\text { Vita- } \\
\text { min } \\
\mathrm{B}_{6} \\
\mathrm{mcg}\end{array}$ & $\begin{array}{c}\text { Vita- } \\
\text { min } \\
\mathrm{B}_{9} \\
\text { mcg }\end{array}$ & $\begin{array}{l}\text { Vita- } \\
\text { min } \\
\mathrm{B}_{12}, \\
\text { mcg }\end{array}$ & $\begin{array}{c}\text { Vita- } \\
\text { min C, } \\
\text { mg }\end{array}$ & $\begin{array}{l}\text { Vita- } \\
\text { min E, } \\
\text { mg }\end{array}$ & $\begin{array}{l}\text { Vita- } \\
\text { min } \\
\text { PP, mg }\end{array}$ \\
\hline $\begin{array}{c}\text { Wheat flour } \\
50 \% \\
\end{array}$ & 0 & 0 & 85 & 20 & 0,15 & 85 & 13,55 & 0 & 0 & 0,75 & 1,5 \\
\hline $\begin{array}{c}\text { Wheat flour } \\
+ \text { sesame } \\
\text { seeds }\end{array}$ & 0,3 & 4 & 195 & 52 & 0,188 & 826 & 10,84 & 0 & 0 & 0,83 & 2,31 \\
\hline $\begin{array}{l}\text { Wheat flour } \\
+ \text { flax seeds }\end{array}$ & 0 & 0 & 232 & 32 & 0,219 & 115 & 19,54 & 0 & 0,06 & 0,631 & 1,508 \\
\hline $\begin{array}{c}\text { Wheat flour } \\
40 \%+5 \% \\
\text { flax seeds }+ \\
5 \% \text { sesame } \\
\text { seeds }\end{array}$ & 0,15 & 2 & 213,5 & 42 & 0,2035 & 98,8 & 15,19 & 0 & 0,03 & 0,7305 & 1,909 \\
\hline
\end{tabular}

Table 4 - Energy value of the prototype and the finished product per $100 \mathrm{~g}$

\begin{tabular}{||l||c||c||c||c||}
\hline \hline Product name & Kcal & Proteins & Fat & $\begin{array}{c}\text { Carbo- } \\
\text { hydrates }\end{array}$ \\
\hline \hline Prototype & 395,85 & 7,95 & 9,3 & 46,73 \\
\hline $\begin{array}{l}\text { Crustilian } \\
\text { with flax and } \\
\text { sesame seeds }\end{array}$ & 400 & 8,21 & 2,1 & 43,34 \\
\hline
\end{tabular}

Table 5 - Determination of physico-chemical parameters of the finished product

\begin{tabular}{||l||c||c|}
\hline \multicolumn{1}{|c|}{ Indicator } & $\begin{array}{c}\text { The norm for } \\
\text { Crustilian }\end{array}$ & $\begin{array}{c}\text { Finished } \\
\text { product }\end{array}$ \\
\hline \hline $\begin{array}{l}\text { Titrated acidity, } \\
\text { degrees }\end{array}$ & 1,0 & 1,0 \\
\hline $\mathrm{pH}$ & 4,95 & 4,93 \\
\hline \hline humidity, $\%$ & 3,8 & 3,8 \\
\hline
\end{tabular}

scription compositions using peanuts and walnuts do not meet our requirements for consistency. The graphic drawing indicates the consistency of the finished crucibles, namely their crunchiness. The least crunchy crustilians with peanuts, which are quite fatty and therefore do not have a crispy consistency. The best results were obtained by crustilian with a combination of flax and sesame seeds. Prescription composition number 3 meets certain requirements and has the highest tasting score, so it is accepted as the main one. According to the obtained indicators, the classic recipe of crustilian is not as crispy as the developed crustilian

Replacement of wheat flour by only $10 \%$ of vegetable raw materials allows to enrich the composition of crustilian several times (Table 3 ).
Thus, based on the above organoleptic evaluation and chemical composition, the recommended recipe is № 3, which contains $40 \%$ wheat flour, $5 \%$ flax seeds and $5 \%$ sesame seeds. The theoretical energy value of the finished product per $100 \mathrm{~g}$ are given in table 4 .

Crustilians with flax and sesame seeds meet the requirements according to normalized physicochemical parameters (Table 5).

\section{Conclusions}

The line of crustilians with a high content of biologically active compounds was developed by introduction of superfoods such as flax seeds, sesame seeds, sunflower and walnuts and peanuts into the product formulation. It has been established that the use of peanuts and walnuts, in the composition, makes the dough less crispy and more fatty. The presence of flax and sesame does not reduce the crunchiness of the finished product, which is characteristic of crustilian, but, on the contrary, slightly increases this figure.

It has been shown that to obtain sheets of proper quality it is necessary to use wheat flour containing 25 $32 \%$ of low gluten. The presence of melange improves the viscosity of the waffle dough. As the amount of melange increases, the strength of the sheet decreases. The introduced components do not change the specific action of the melange, which correlates with the results of the above organoleptic evaluation.

It is proved that the index of nutritional density of crustilian made according to the developed recipe in comparison with the prototype is characterized by an increase in the index of nutritional density by three times, while the mass fraction of macronutrients increases from 1.26 to 2.5 times, depending on the micronutrient. Increases by only 1.1 times.

\section{REFERENCES}

1. Pavuk M., Lebedinets 'V. Zbahachennya vafel 'nikh napivfabrikativ biolohichno tsinnoyu roslinnoyu sirovinoyu // Materiali naukovoyi konferentsiyi studentiv / L'vivs`kiy torhovel’no-ekonomichniy universitet. L'viv: L'vivs koho torhovel no-ekonomichnoho universitetu, 2020. S. 255.

2. Mashir N. P., Palamarek K. V. Vikoristannya netraditsiynoyi sirovini u virobnitstvi konditers $k i k h$ virobiv likuval 'no-profilaktichnoho priznachennya // Zbirnik naukovikh prats`/ Odes`ka natsional’na akademiya kharchovikh tekhnolohiy. . Odesa, 2009. S. 169.

3. Miroshnik Yu. A., Dotsenko V. F. Dosvid vikoristannya poroshkiv z netraditsiynoyi roslinnoyi sirovini $v$ tekhnolohiyi boroshnyanikh konditers kikh virobiv // "Modern engineering and innovative technologies». 2019., vip. 2 T. 8. S. 65-71. 
УДК 668.681-021.4:005.936.41-035.2(083.1)

Л.М. Тележенко, д-р техн. наук, професор ${ }^{1}$, E-mail: telegenko@ukr.net ORCID 0000-0001-6675-2625, ResearcherID: O-8034-2018

Scopus Author ID: 57194025461

М.С. Нападовська, аспірант², E-mail: marinapadovska@gmail.com ORCID 0000-0003-2682-5003

T. Пастернак, магістр, E-mail: tanusha.pasternak@ukr.net Одеська національна академія харчових технологій вул. Канатна, 112, 65039 м. Одеса, Украйна, $+38487124113$

\title{
РОЗРОБКА РЕЦЕПТУРИ КРУСТІЛЬЯНІВ 3 ПІДВИЩЕНОЮ ХАРЧОВОЮ ЦІННІСТЮ
}

\begin{abstract}
Анотація
Однією із найважливіших проблем харчування населення є значна калорійність борошняних кондитерських виробів, через їхне перенасичення на вуглеводну та жирову складову. Така тенденція призводить до дефіциту мікронутрієнтів, а в подальшому і до проблем із обміном речовин та погіршенням стану здоров'я. $B$ останні роки відбувається розширення асортименту вафель, вдосконалення технології за рахунок більш широкого впровадження різних інгредієнтів рослинного походження. Крустільян ие хрусткий виріб або складова страви, які мають хрустку текстуру (вафлі, злакові хлібиі) або поверхню (скоринка хліба чи картопляні кульки із смаженою корочкою). Крустільян також використовують як прошарок для тортів чи десертних страв, що зазвичай складається з вафельної крихти, подрібнених горіхів і розтопленого темного шоколаду. $\epsilon$ ще дуже багато варіачій для виготовлення крустельянів. Спектр застосування крустильяну при виготовленні солодких страв надзвичайно широкий. Харчова цінність крустільянів визначається складом сировини і може бути значно підвищена за рахунок раџіонального підбору компонентів, введення в рещептуру збагачувачів, а також технологічної обробки, що дозволяє підвищити їхню засвоюваність. Удосконалення технології вафель крустільянів шляхом підвищення їхньої харчової щільності дозволить розиирити асортимент продукції із функиіональними інгредієнтами, а збагачення мікронутрієнтного складу за рахунок иінної рослинної сировини покращить харчову цінність та органолептичні показники готового продукту. Розроблено лінійку крустільянів з підвищеним вмістом біологічно активних сполук завдяки уведенню у рецептури продукту суперфудів таких як насіння льону, кунжуту, соняшника та горіхів волоських і арахісу. Встановлено, що використання арахісу та волоського горіху, у складі, робить тісто мени хрустким і більш жирним. Наявність льону і кунжуту не зменшує хрусткість готового продукту, властиву крустільянам, а, навпаки, дещо підвищує ией показник. Доведено, що індекс харчової щільності крустільяну виготовленого за розробленою рецептурою у порівнянні із прототипом характеризується підвищенням індексу харчової щільності у три рази, в той час як масова частка макронутрієнтів збільшується від 1,26 до 2,5 разів, в залежності від мікронутрієнту, а калорійність крустільяну зростає лише y 1,1 разів.
\end{abstract}

Ключові слова: крустільян, вафельні вироби, рослинна сировина, біологічна цінність, харчова иінність, харчова щільність.

\section{ЛІТЕРАТУРА}

1. Павук М. , Лебединець В. Т. Збагачення вафельних напівфабрикатів біологічно иінною рослинною сировиною // Матеріали наукової конферениії студентів / Львівський торговельно-економічний університет. Львів: Львівського торговельно-економічного університету, 2020. С. 255.

2. Машир Н. П., Паламарек К. В. Використання нетрадиційної сировини у виробництві кондитерських виробів лікувально-профілактичного призначення // Збірник наукових праць / Одеська національна академія харчових технологій. . Одеса, 2009. С. 169.

3. Мирошник Ю. А., Доценко В. Ф. Досвід використання порошків з нетрадиційної рослинної сировини в технології борошняних кондитерських виробів // «Modern engineering and innovative technologies». 2019., вип. 2 T. 8. C. 65-71.

\section{Received 24.06.2020 \\ Reviewed 17.07.2020}

Revised 23.09.2020

Approved 01.12.2020

Cite as Vancouver Citation Style

Telezhenko L., Napadovska M., Pasternak T. Development of a recipe for crustilians with high nutritional value. Grain products and mixed fodder's, 2020; 20 (4, 80): 24-28. DOI https://doi.org/

Cite as State Standard of Ukraine 8302:2015

Development of a recipe for crustilians with high nutritional value. Modification properties of confectionary flour products with synbiotic / Telezhenko L. et al. // Grain Products and Mixed Fodder's. 2020. Vol. 20, Issue 4 (80). P. 24-28. DOI https://doi.org 